\title{
Pendampingan Gerakan Literasi Sains (GLS) Di SDN Girimoyo 2 Malang
}

\author{
Erna Yayuk ${ }^{1}$, Kuncahyono ${ }^{2}$, Arina Restian ${ }^{3}$ \\ 1,2,3 Prodi Pendidikan Guru Sekolah Dasar Universitas Muhammadiyah Malang \\ 1ernayayuk17@umm.ac.id \\ ${ }^{2}$ kuncahyono@umm.ac.id \\ 3arina.poenya@gmail.com
}

\begin{abstract}
ABSTRAK
Literasi sains merupakan pengetahuan dan kecakapan ilmiah dalam mengidentifikasi pertanyaan, memperoleh pengetahuan baru, menjelaskan fenomena ilmiah, serta mengambil simpulan berdasar fakta, memahami karakteristik sains, kesadaran bagaimana sains dan teknologi membentuk lingkungan alam, intelektual, dan budaya, serta kemauan untuk terlibat dan peduli terhadap isu-isu yang terkait sains. National Research Council (2012) menyatakan bahwa rangkaian kompetensi ilmiah yang dibutuhkan pada literasi sains mencerminkan pandangan bahwa sains adalah ansambel dari praktik sosial dan epistemik yang umum pada semua ilmu pengetahuan, yang membingkai semua kompetensi sebagai tindakan. Tujuan dari pendampingan ini adalah membekali guru-guru dalam implementasi gerakan literasi sekolah terutama gerakan litersi sains. Metode kegiatan terbagi menjadi tiga tahapan meliputi workshop GLS, implementasi GLS, dan Evaluasi Refleksi. Hasil Pendampingan yang dilakukan meliputi pendampingan penyusunan program literasi Sains oleh sekolah, Manual program pelaksanaan GLS dan contoh setting kelas penunjang GLS, dan terbentuknya setting kelas dengan desain sudut baca pada masing-masing kelas sebagai unsur penunjang literasi sains.
\end{abstract}

Kata kunci: Pendampingan, Gerakan Literasi Sains (GLS)

\section{PENDAHULUAN}

Sejarah peradaban umat manusia menunjukkan bahwa bangsa yang maju tidak dibangun hanya dengan mengandalkan kekayaan alam yang melimpah dan jumlah penduduk yang banyak. Bangsa yang besar ditandai dengan masyarakatnya yang literat, yang memiliki peradaban tinggi, dan aktif memajukan masyarakat dunia. Keberliterasian dalam konteks ini bukan hanya masalah bagaimana suatu bangsa bebas dari buta aksara, melainkan juga yang lebih penting, bagaimana warga bangsa memiliki kecakapan hidup agar mampu bersaing dan bersanding dengan bangsa lain untuk menciptakan kesejahteraan dunia. Dengan kata lain, bangsa dengan budaya literasi tinggi menunjukkan kemampuan bangsa tersebut berkolaborasi, berpikir kritis, kreatif, komunikatif sehingga dapat memenangi persaingan global.

Sebagai bangsa yang besar, Indonesia harus mampu mengembangkan budaya literasi sebagai prasayarat kecakapan hidup abad ke21 melalui pendidikan yang terintegrasi, mulai dari keluarga, sekolah, sampai dengan masyarakat. Penguasaan enam literasi dasar yang disepakati oleh World Economic Forum pada tahun2015 menjadi sangat penting tidak hanya bagi peserta didik, tetapi juga bagi orang tua dan seluruh masyarakat. Enam literasi dasar tersebut mencakup literasi baca tuls, litersi numerasi, literasi sains, literasi digital, literasi finansial, dan literasi budaya dan kewargaan.

Pintu masuk untuk mengembangkan budaya literasi bangsa adalah melalui penyediaan bahan bacaan dan peningkatan minat baca anak. Sebagai bagian penting dari penumbuhan budi pekerti, minat baca anak perlu dipupuk sejak usia dini mulai dari lingkungan keluarga. Minat baca yang tinggi, didukung dengan ketersediaan bahan bacaan yang bermutu dan terjangkau akan mendorong pembiasaan membaca dan menulis, baik di sekolah maupun dimasyarakat. Dengan kemampuan membaca ini pula literasi dasar berikutnya (numerasi, sains, digital, finansial, serta buadaya dan kewarganegaraan) yang dapat ditumbuh kembangkan.

Untuk membangun budaya literasi pada seluruh ranah pendidikan (keluarga, sekolah, dan masyarakat), sejak tahun 2006 Kementerian Pendidikan dan Kebudayaan menggiatkan gerakan Literasi Nasional (GLN) sebagai bagian dari implementasi Peraturan 
Menteri Pendidikan dan Kebudayaan Nomor 23 Tahun 2015 tentang penumbuhan Budi Pekerti. Layaknya suatu gerakan, pelaku GLN tidak didominasi oleh jajaran Kementerian Pendidikan dan Kebudayaan, tetapi digiatkan pula oleh para pemangku kepentingan, seperti penggiat literasi, akademisi, organisasi profesi, dunia usaha, dan kementerian/lembaga lain. Pelibatan ekosistem pendidikan sejak penyusunan konsep, kebijakan, penyediaan materi pendukung, sampai pada kampanye literasi sangat penting agar kebijakan yang dilaksanakan sesuai dengan harapan dan kebutuhan masyarakat. GLN diharapkan menjadi pendukung keluarga, sekolah, dan masyarakat mulai dari perkotaan sampai ke wilayah terjauh untuk perperan aktif dalam menumbuhkan budaya literasi. Salah satu bentuk gerakan literasi nasional adalah literasi Sains.

Literasi sains dapat diartikan sebagai pengetahuan dan kecakapan ilmiah untuk mampu mengidentifikasi pertanyaan, memperoleh pengetahuan baru, menjelaskan fenomena ilmiah, serta mengambil simpulan berdasar fakta, memahami karakteristik sains, kesadaran bagaimana sains dan teknologi membentuk lingkungan alam, intelektual, dan budaya, serta kemauan untuk terlibat dan peduli terhadap isu-isu yang terkait sains (OECD, 2016). National Research Council (2012) menyatakan bahwa rangkaian kompetensi ilmiah yang dibutuhkan pada literasi sains mencerminkan pandangan bahwa sains adalah ansambel dari praktik sosial dan epistemik yang umum pada semua ilmu pengetahuan, yang membingkai semua kompetensi sebagai tindakan.

Literasi sains merupakan kunci utama untuk menghadapi berbagai tantangan pada abad XXI untuk mencukupi kebutuhan air dan makanan, pengendalian penyakit, menghasilkan energi yang cukup, dan menghadapi perubahan iklim (UNEP, 2012). Banyak isu yang timbul di tingkat lokal ketika individu berhadapan dengan keputusan berkaitan dengan praktik-praktik yang memengaruhi kesehatan dan persediaan makanan, penggunaan bahan dan teknologi baru yang tepat, dan keputusan tentang penggunaan energi. Sains dan teknologi memiliki kontribusi utama terkait dengan semua tantangan di atas dan semua tantangan tidak akan terselesaikan jika individu tidak memiliki kesadaran sains.

Hal ini tidak berarti mengubah setiap orang menjadi pakar sains, tetapi memungkinkan mereka untuk berperan dalam membuat pilihan yang berdampak pada lingkungan dan dalam arti yang lebih luas memahami implikasi sosial dari perdebatan para pakar. Hal ini juga berarti bahwa pengetahuan sains dan teknologi berbasis sains berkontribusi signifikan terhadap kehidupan pribadi, sosial, dan profesional. Literasi sains membantu kita untuk membentuk pola pikir, perilaku, dan membangun karakter manusia untuk peduli dan bertanggung jawab terhadap dirinya, masyarakat, dan alam semesta, serta permasalahan yang dihadapi masyarakat modern yang sangat bergantung pada teknologi. Individu yang literat sains harus dapat membuat keputusan yang lebih berdasar. Mereka harus dapat mengenali bahwa sains dan teknologi adalah sumber solusi. Sebaliknya, mereka juga harus dapat melihatnya sebagai sumber risiko, menghasilkan masalah baru yang hanya dapat diselesaikan melalui penggunaan sains dan teknologi. Oleh karena itu, individu harus mampu mempertimbangkan manfaat potensial dan risiko dari penggunaan sains dan teknologi untuk diri sendiri dan masyarakat. Literasi sains tidak hanya membutuhkan pengetahuan tentang konsep dan teori sains, tetapi juga pengetahuan tentang prosedur umum dan praktik terkait dengan inkuiri saintifik dan bagaimana memajukan sains itu sendiri. Untuk semua alasan tersebut, literasi sains dianggap menjadi kompetensi kunci yang sangat penting untuk membangun kesejahteraan manusia di masa sekarang dan masa depan.

Melihat paparan di atas, tersirat bahwa gerakan literasi ini sangat penting untuk dilakukan terutama di SDN Girimoyo 2 Malang. Berdasarkan hasil analisis bahwa kualitas SDM maupun peserta didik dalam konteks literasi disana dirasa belum memadai dan belum optimal. Sedangkan di era globalisasi ini, guru sangat dituntut meningkatkan profesionalitasnya sebagai pengajar dan pendidik. Sebagai generasi penerus bangsa pun, peserta didik harus mampu berpola pikir kritis, inovatif, berkarakter untuk peduli dan bertanggungjawab terhadap dirinya sendiri, masyarakat dan alam sekitarnya. Oleh karena itu, sebagai sikap proaktif dari gambaran diatas, dosen PGSD Universitas Muhammadiyah Malang memandang perlu diadakan upaya pendampingan terhadap guru-guru melalui Gerakan Literasi Sekolah (GLS). 


\section{METODE KEGIATAN}

Secara umum pelaksanaan kegiatan pendampingan secara intensif dilakukan dengan tahapan sebagai berikut:

1. Workshop Gerakan Literasi Sains (GLS) Tim Pengabdian:

Kegiatan diawali dengan proses sosialisasi program pengabdian. Kemudian dilanjutkan dengan pemberian materi tentang GLS. Materi yang diberikan mencakup tentang wacana GLS, sasaran GLS dan strategi GLS. Setelah pemberian materi, peserta diminta untuk melakukan analisis kebutuhan, meliputi analisis karakter siswa, analisis kurikulum, analisis materi, dan ketersediaan sarana dan prasarana. Analisis ini diperlukan untuk mengetahui jenis GLS yang cocok untuk dikembangkan di masing-masing sekolah. Pada akhir kegiatan diharapkan peserta mampu membuat sebuah program GLS yang nantinya akan diimplementasikan di sekolah tersebut.

Guru:

Menghadiri acara workshop yang diawali dengan kegiatan sosialisasi kegiatan pengabdian dan dilanjutkan materi GLS. Adapun materi yang harus dipahami adalah mengenai GLS, Jenis-jenis GLS, sasaran dan strategi tiap GLS. Guru melakukan analisis kebutuhan, meliputi analisis karakteristik siswa, kurikulum, materi dan ketersediaan bahan. Dengan analisis ini, guru akan mampu menentukan jenis GLS yang dikembangkan.

\section{Pendampingan Program GLS}

a. Tim Pengabdian :

Draft rancangan penyusunan program GLS yang dihasilkan oleh peserta pelatihan, selanjutnya akan dikembangkan menjadi model GLS di SD tersebut. Selama proses penyusunan, guru-guru akan mendapat pendampingan secara intensif dari tim pengabdian. Pendampingan juga dilaksanakan sebagai bentuk kolaborasi tim pengabdian dan guru dalam perencanaan Gerakan Literasi Sekolah.

b. Guru:

Pada tahap ini, para guru akan menyusun GLS sesuai dengan rancangan pengembangan yang telah disepakati serta berkolaborsi dengan tim pengabdian dalam rangka penyusunan program GLS.

Pendampingan dilakukan dengan cara minimal 3 kali tatap muka sesuai dengan kebutuhan. Jadwal disesuaikan dengan situasi dan kondisi yang ada di setiap sekolah.

\section{Implementasi program GLS}

a. Tim Pengabdian :

Program GLS yang telah dibuat akan diimplementasikan pada pembelajaran di kelas pada masing-masing sekolah bahkan bisa dilakukan secara terpadu. Saat pembelajaran, guru akan didampingi oleh tim pengabdian. Kegiatan ini akan didokumentasikan dalam bentuk rekaman video. Akhir pembelajaran, tim pengabdian dan guru mengevaluasi bersama-sama terrhadap efektivitas pelaksanaan GLS.

b. Guru:

Melaksanakan proses pembelajaran dengan menggunakan rencana program GLS yang sudah disepakati.

\section{Evaluasi dan refleksi}

Pada tahap ini dilakukan evaluasi terhadap pelaksanaan GLS yang yang telah diimplementasikan dalam proses pembelajaran di kelas. Selanjutnya, tim pengabdian dan guru akan bekerjasama menyusun buku manulal pelaksanaan program GLS. Pada kegiatan ini juga dilaksanakan refleksi terhadap seluruh kegiatan yang telah dilaksanakan. Refleksi diawali dengan tanya jawab, dan diskusi dengan guru (FGD) focus group disccusion sebagai bahan pertimbangan atau rekomendasi pada kegiatan selanjutnya.

\section{HASIL DAN PEMBAHASAN}

1. Workshop dan pelatihan GLS (gerakan Literasi Sains)

Pelaksanaan workshop GLS (gerakan Literasi Sains) dilaksanakan di SDN Girimoyo 2 Kabupaten Malang pada tanggal 21 April 2018. Pelaksanaan workshop dilakukan selama sehari bersama tim pengabdian masyarakat yang terdiri atas 3 orang dosen PGSD FKIP UMM Ketiga dosen tersebut hadir untuk mengisi kegiatan Workshop dan pelatihan GLS (gerakan Literasi Sains) Kegiatan ini diikuti oleh guru-guru SD Girimoyo 2 Kabupaten Malang mulai dari kelas I sampai dengan Kelas VI. 


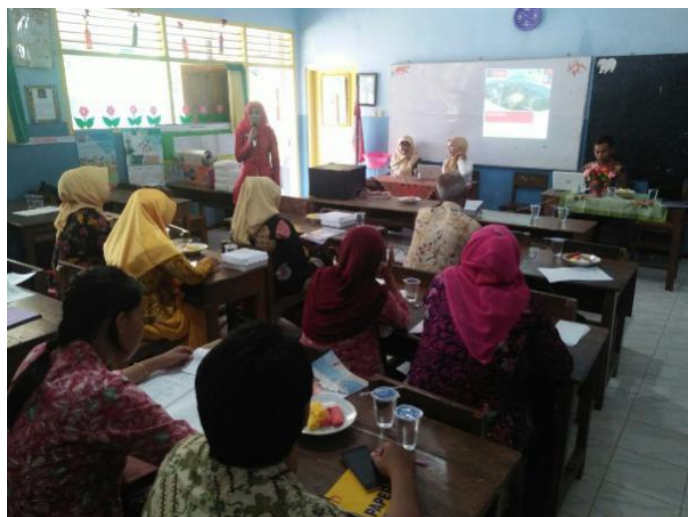

Gambar 1. Workshop GLS (Pemateri 1)

Kegiatan workshop yang dilakukan bertujuan untuk memberikan pemahaman terkait Literasi sains adalah bahwa penggunaan sains dan teknologi bukan hanya untuk memahami alam semesta. Literasi sains terdiri atas beberapa tingkatan. Tingkat literasi sains yang terendah disebut literasi sains praktis atau fungsional yang merujuk pada kemampuan seseorang untuk dapat hidup sehari-hari, sebagai konsumen dari produk-produk sains dan teknologi. Ini dihubungkan dengan kebutuhan untuk sekolah di tingkat sekolah dasar.

Kepada guru-guru yang terlibat, melalui workshop ini diharapkan guru-guru memiliki pemahaman dan kompetensi dalam memahami literasi dan macam-macmnya, serta lebih spesifik memahami konsep literasi sains. Kepala sekolah juga diharapkan menjadi fasilitator dan motivator sehingga guru-guru memahami dan mau mengimplementasikan literasi dalam pembelajaran. Sehingga berdampak pada kemampuan guru terutama kemampuan memanfaatkan sains dan teknologi sebagai kontribusi memahami alam semesta.

Kegiatan yang dilakukan oleh tim dosen pertama-tama mempersiapkan topik dan materi worksop dengan membagi menjadi 3 sesi. Sesi 1 yaitu penyampaian materi I oleh Erna Yayuk tentang Gerakan Literasi Nasional dan Sains. Materi ke 2 disampaikan oleh Kuncahyono dan Arina Restian tentang Desain kelas melalui Gerakan Literasi Sains.

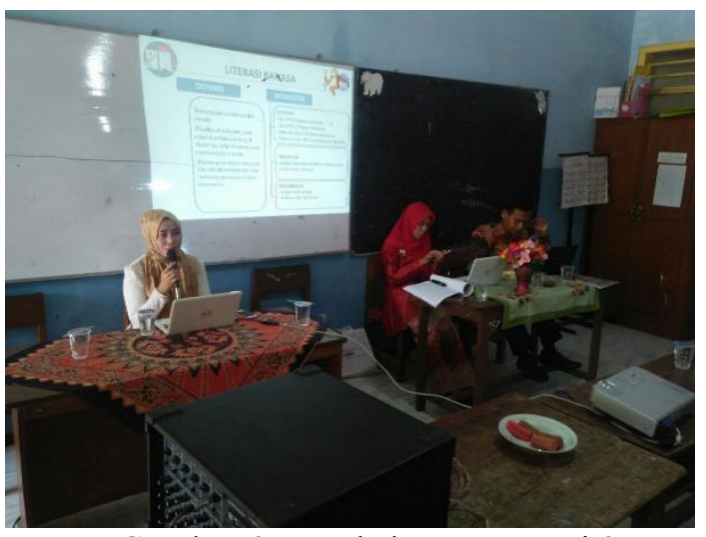

Gambar 2. Workshop pemateri 2

Sesi 3 merupakan FGD (Focus Group Discussion) yang dipandu oleh 3 orang pemateri sekaligus sesi tanyajawab untuk berbagi pengalaman, kesulitan, dan kemudahan dalam menyusun program GLS.

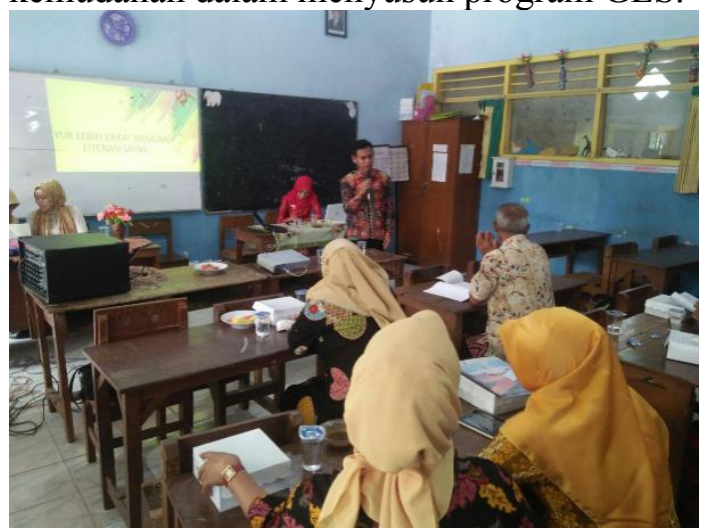

Gambar 3. Workshop GLS (Pemateri 3)

Berdasarkan hasil workshop yang sudah dilakukan oleh tim pengabdian, manfaat yang dirasakan oleh guru-guru yaitu 1) guruguru memiliki pengalaman baru terkait Gerakan literasi Nasional terutama GLS, 2) guru-guru memiliki keterampilan baru terutama dalam mendesain konsep kelas dengan memadukan GLS, 3) inovasi baru dalam memperluas akses siswa dalam implementasi GLS di setiap kelas melalui penerapan sudut baca.

\section{Pendampingan Penyusunan Program GLS}

Kegiatan selanjutnya dari tindak lanjut workshop adalah melakukan pendampingan dalam penyusunan program GLS. Pada program ini tim pengabdi bersama dengan tim guru-guru menyusun manua program untuk merealisasikan GLS di masing-masing kelas. Selama proses penyusunan program, guru-guru mendapat bimbingan/pendampingan secara maksimal. Tim pendampingan terdiri atas 3 Dosen, yang bertugas mendampingi dan 
mengarahkan langkah-langkah membuat program manual GLS. Guru-guru merancang setting kelas agar pemanfaatan dan kontribusi GLS dapat diterapkan di kelas.

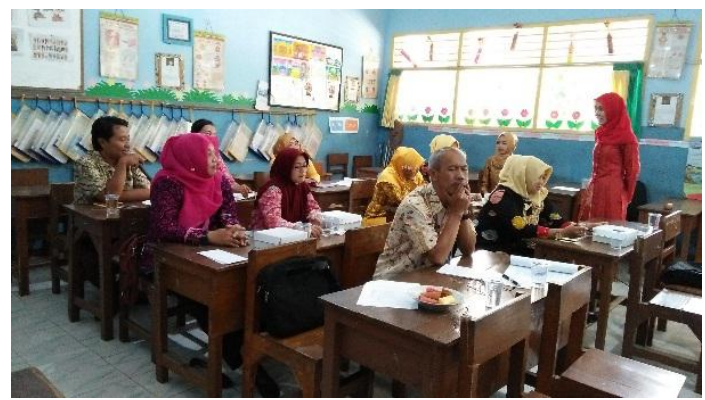

Gambar 4. Pendampingan GLS

Kegiatan pendampingan yang dilakukan oleh tim pengadian dijadwalkan sesuai dengan kesepakatan antara pihak sekolah dan tim pengabdian. Adapun pelaksanaan pengabdian dilakukan sebanyak dua kali pendampingan. Berikut rincian kegiatan pendampingan yang dilakukan oleh tim pengabdian;

\section{1) Pendampingan ke 1}

Tahap pendampingan pertama dilakukan pada hari sabtu tanggal 5 mei 2018. Pelaksanaan pendampingan berfokus pada teknik dalam merancang desain/setting kelas. Adapun hasil kemajuan dari peserta pendampingan sebagai berikut:

a. Desain setting kelas dalam pengembangan penunjang sarana belajar. Pemanfaatan sarana penunjang ini digunakan sebagai sumber belajar Sains sehingga kelas dapat dimanfaatkan sebagai penujang literasi. Adapun bentuk sarana penunjang yang dapat dikembangkan meliputi menghiasi dinding, menghiasi papan pengumungan/mading kelas sesuai dengan informasi sains.

b. Membuat desain mini laboratorium. Kegiatan ini dapat dilakukan dengan menyediakan alat-alat laboratorium yang memadai sehingga laboratorium mini dapat digunakan siswa untuk melakukan eksperimen.

c. Desain sudut baca pada ruang kelas. Penyediaan sudut baca di kelas yang berisi buku-buku sains dan beragam buku lainnya. Sudut baca ini mendekatkan buku dengan peserta didik di kelasnya masing-masing. Peserta didik dapat leluasa membaca dan memilih bahan bacaan yang dikehendaki.

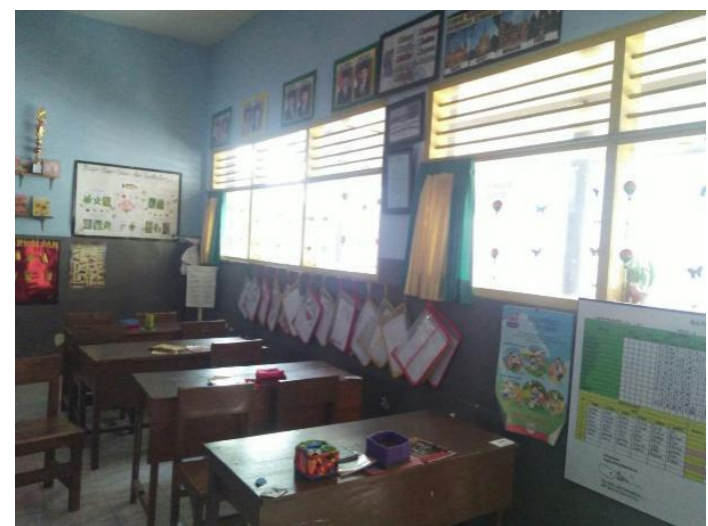

Gambar 5. Desain Setting Kelas GLS

\section{2) Pendampingan ke 2}

Tahap pendampingan kedua dilakukan pada hari sabtu tanggal 12 Mei 2018. Hasil pendampingan tahap 2 (dua) ini berfokus pada penerapan/implementasi desain yang sudah dibuat oleh guru-guru yang meliputi sudut baca kelas. Hasil desain yang sudah layak, dapat diterapkan pada masing-masing kelas. Berikut adalah paparan hasil sudut baca kelas GLS.

a. Sudut baca kelas dilengkapi dengan koleksi buku yang ditata secara menarik untuk menumbuhkan minat baca siswa. Koleksi buku yang dikelola sangat beragam mulai dari buku ilmu pengatahuan sampai dengan buku cerita. Dalam hal ini dapat disimpulkan buku yang tersedia terdiri atas buku pelajaran dan non pelajaran.

b. Sudut Baca Kelas adalah sudut di ruangan kelas yang digunakan untuk memajang koleksi bacaan dan karya siswa. Hasil karya siswa dapat dipajang agar siswa merasa bahwa pekerjaannya adalah hasil terbaik dan dapat meningkatkan motivasinya untuk menghasilkan karya yang lebih baik lagi.

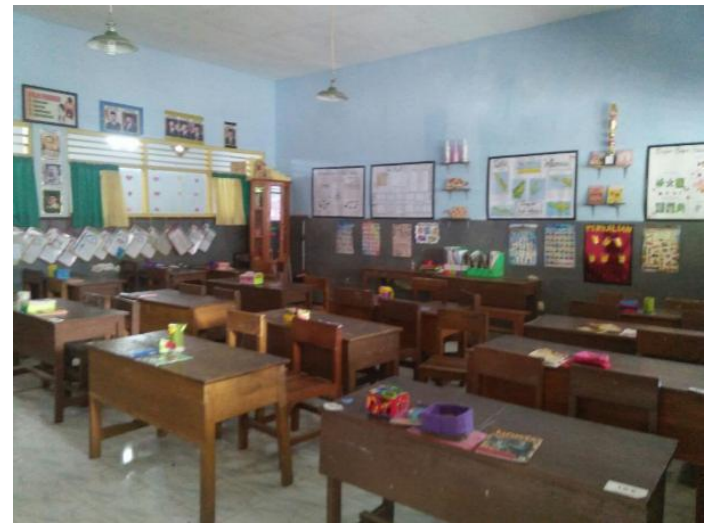

Gambar 6. Setting sudut baca GLS

Berdasarkan hasil pendampingan terdapat dampak yang dirasakan pihak sekolah terutama guru kelas sebagai pilot projek 
penerapan GLS (Gerakan Literasi sekolah). Adapun dampak yang dirasakan yaitu siswa menjadi termotivasi untuk membiasakan membaca sehingga minat baca siswa meningkat. Hal ini sejalan dengan hasil penelitian Faradina, 2017 bahwa pengaruh program gerakan literasi sekolah terhadap minat baca siswa signifikan. Gerakan literasi sekolah juga menumbuhkan budaya literasi dan meningkatkan minat baca siswa.

c. Sudut Baca Kelas berperan sebagai perpanjangan fungsi perpustakaan, yaitu sebagai sarana perpustakaan mini yang ada di dalam kelas sebagai bentuk mendekatkan buku kepada siswa. Perpustakaan mini dapat digunakan oleh guru dan siswa secara langsung sebagai pemanfaatan sumber belajar.

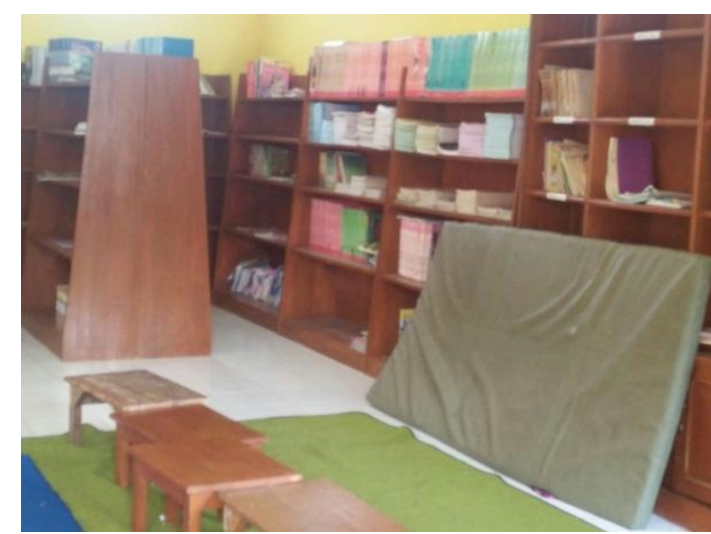

Gambar 7. Hasil setting perpustakaan kelas GLS

Dapat dikatakan bahwa penerapan sudut baca di kelas dapat dijadikan sebagai kontribusi untuk menarik perhatian siswa. Hal ini sejalan dengan Faizah (2016:17) Sudut Baca Kelas adalah sebuah sudut di kelas yang dilengkapi dengan koleksi buku yang ditata secara menarik untuk menumbuhkan minat baca siswa.

Berdasarkan hasil tersebut dapat dikatakan bahwa penataan sudut baca yang sesuai dan tepat terdapat dampak positif yang dirasakan siswa dan guru. Siswa menjadi senang dan termotivasi untuk memperbanyak literasi membaca, guru juga mudah untuk mencari sumber dan literatur dalam menyampaikan materi pembelajaran.

\section{3) Evaluasi dan refleksi}

Pada tahap ini dilakukan evaluasi terhadap pelaksanaan GLS yang yang telah diimplementasikan dalam proses pembelajaran di kelas. Pada kegiatan ini juga dilaksanakan refleksi terhadap seluruh kegiatan yang telah dilaksanakan. Refleksi diawali dengan tanya jawab, dan diskusi dengan guru sebagai bahan pertimbangan atau rekomendasi pada kegiatan selanjutnya.

Hasil evaluasi dan refleksi yang diterapkan bahwa guru-guru dalam membuat program dan setting kelas GLS mendapat sambutan baik dari pihak sekolah terutama kepala Sekolah karena guru-guru sudah mengaplikasi desain setting kelas GLS berupa menghias kelas dengan literasi sain, membuat laboratorium mini, dan desain sudut baca di masing-masing kelas.

Lebih lanjut terdapat temuan lain sejalan dengan hasil pendampingan menunjukkan bahwa gerakan literasi sains yang sudah dilakukan dapat diaplikasikan guru untuk menerapkan pendekatan saintifik dalam pembelajaran. Guru merespon bahwa semakin mudah untuk melaksanakan pendekatan saintifik sehingga siswa menjadi tertarik dalam pemebelajaran. Sebagaimana hasil penelitian Ariani, 2018 menyatakan bahwa penerapan pendekatan saintifik pada pembelajaran menunjukkan dapat meningkatkan kualitas pembelajaran sehingga hasil pembelajaran lebih bermakna.

\section{KESIMPULAN \& SARAN}

Berdasarkan hasil pelatihan dan pendampingan yang sudah dicapai, maka kesimpulan dari pengabdian ini sebagai berikut: a. Hasil secara umum dari kegiatan pelatihan dan pendampingan yang dilakukan di SD Girimoyo 2 Kabupaten Malang berlangsung dengan baik dan maksimal. Kegiatan pelatihan menunjukkan hasil yang baik di mana guru-guru antusias mengikuti kegiatan dari awal sampai akhir. Berdasarkan hasil FGD guru-guru merasa senang karena mereka mendapat ilmu baru dan tentunya meningkatkan kompetensi guru di bidang literasi terutama GLS. Lebih lanjut hasil pelatihan yang dilakukan oleh tim menunjukkan respon positif dari guruguru dengan dibuktikan desain ruang kelas berbasis GLS.

b. Pendampingan penyusunan program GLS dilakukan oleh Tim pendapingan yang terdiri atas 3 Dosen, yang bertugas mendampingi dan mengarahkan dalam mendesain program GLS di masing-masing kelas. Guru-guru merancang program dan setting kelas berbasis GLS. Kegiatan pendampingan yang dilakukan oleh tim 
pengadian dijadwalkan sesuai dengan kesepakatan antara pihak sekolah dan tim pengabdian

c. Hasil evaluasi dan refleksi yang diterapkan bahwa guru-guru dalam membuat program dan setting kelas GLS mendapat sambutan baik dari pihak sekolah terutama kepala Sekolah karena guru-guru sudah mengaplikasi desain setting kelas GLS berupa menghias kelas dengan literasi sain, membuat laboratorium mini, dan desain sudut baca di masing-masing kelas.

Berikut ini beberapa saran yang diharapkan dapat membantu penelitian selanjutnyasebagai berikut:

a. Strategi peningkatan kecakapan sains perlu dilakukan secara berkelanjutan dan melibatkan seluruh warga sekolah, keluarga, dan semua komponen masyarakat sudah dihasilkan oleh guruguru.

b. Bagi guru-guru sebelum memulai pembelajaran senantiasa dapat menerapkan pembiasaan kepada siswanya untuk membaca/literasi agar wawasan siswa bertambah.

c. Program GLS agar dapat dilaksanakan tidak hanya di sekolah, tetapi di dalam keluarga dan masyarakat luas.

\section{DAFTAR PUSTAKA}

Ariani, Dessy Noor. 2018. Pendampingan Lesson Study Untuk Meningkatkan Kompetensi Guru Sekolah Dasar di KKG Gugus Sungai Miai Banjarmasin dalam Menerapkan Pendekatan Saintifik Menggunakan Kurikulum 2013. Jurnal Publikasi Pendidikan Vol 8 (2) 113-117 http://ojs.unm.ac.id/pubpend/article/vie w/5636/pdf_45

Beers, C. S., Beers, J. W., \& Smith, J. O. 2009. A Principal's Guide to Literacy Instruction. New York: Guilford Press.

Faizah, dewi Utama, dkk. 2016. Panduan Gerakan Literasi Sekolah di Sekolah Dasar. Jakarta: Direktorat Pembinaan Sekolah Dasar Direktorat Jenderal Pendidikan Dasar dan Menengah Kementerian Pendidikan dan Kebudayaan.

Fananta, Muhammad Randy, dkk. 2017. Materi Pendukung Literasi Sains Gerakan Literasi Sains. Jakarta: Kementerian Pendidikan dan Kebudayaan

National Research Council (2012), A
Framework for K-12 Science Education: Practices, Crosscutting Concepts, and Core Ideas, Committee on a Conceptual Framework for New K-12 Science Education Standards, Board on Science Education, Division of Behavioral and Social Sciences and Education, Washington, DC.

Faradyna, Nindya. 2017. Pengaruh Program Gerakan Literasi Sekolah terhadap minat Baca siswa di SD Islam Terpadu Muhammadiyah An-Najah. Jurnal Hanata Widya Volume 6 (8). http://journal.student.uny.ac.id/ojs/index. php/fipmp/article/view/9280/8962Jatino m klaten

OECD 2016. PISA 2015 Assessment and Analytical Framework: Science, Reading, Mathematic and Financial Literacy, PISA.

OECD Publishing, Paris. http://dx.doi.org/10.1787/97892642554

25-en OECD (2016), PISA 2015

Results in Focus, PISA, OECD Publishing, Paris. PP No. 13 tahun 2015 pasal I ayat 23

UNEP (2012), 21 Issues for the 21st Century: Result of the UNEP Foresight Process on Emerging Environmental Issues, United Nations Environment Programme (UNEP), Nairobi, Kenya, www.unep.org/pdf/Foresight Report21 Issues for the 21st Century.pdf.

Kementerian Pendidikan dan Kebudayaan. 2013 Standar Nasional Pendidikan.

Undang-Undang Republik Indonesia, Nomor: 20 Tahun 2003 tentang Sisdiknas (Sistem Pendidikan Nasional), Penerbit Fokusmedia Bandung.

Wassman, Rose. \& Rinsky, Lee A. 1998. Effective Reading in a Changing World. England:Penguin. 